\title{
Development of Prediction Equations for Tomato Leaf Curl Virus on Tomato at Different Dates of Planting using Logistic and Gompertz Model
}

\author{
Madhumita Maity, Poly Saha* and Partha Sarathi Nath \\ Department of Plant Pathology, Bidhan Chandra Krishi Viswavdyalaya, \\ Nadia, West Bengal, India \\ *Corresponding author
}

\section{Keywords}

Area under disease progress curve (AUDPC), Dates of planting (DOP), Logistic and gompertz model, Prediction equation, Tomato leaf curl virus (ToLCV) and weather parameters

Article Info

Accepted:

10 April 2019

Available Online:

10 May 2019

\section{A B S T R A C T}

Tomato leaf curl virus (ToLCV) has become a major threat of Tomato (Solanum lycopersicum) production in the world including tropical and subtropical tomato growing regions due to its the endemic presence. The aim of this study is to develop a forewarning strategy for the farmers. The components included in the experiment were, a susceptible tomato variety "Patharkuchi" planted at 15 days interval starting from16th August to 29th December during both the experimental year 2012-13 and 2013-14 under field condition. Different dates of planting also allowed the plants to interact with the different weather factors prevailed through out the growing period. Here, six independent weather variables like maximum and minimum temperature and their differences, maximum and minimum relative humidity and rainfall were considered and natural epiphytotic conditions were permitted. Disease severity was measured and expressed as AUDPC. Prediction equations were developed for each treatment separately through step down multiple regression analysis which showed that different meteorological factors having different influence on disease severity and these were explained after logistic and gompertz transformation of the realized observed value of the disease severity (expressed as AUDPC). Logitic and gompertz are the two transformation models through which the disease progress curve move over time and its comparative expression are also presented graphically in this study. Different dates of planting showed differences in disease severity. Lowest disease severity was found when tomato was planted in (D1=16th August) (AUDPC=94.08) and 97.01) and maximum disease severity was noticed (D4=30th September) (AUDPC=101.91 and 102.66) in the two respective years. Results disclosed that two models tested were not equally fit for predicting disease progress curve in every treatments, though both the models can be used to express disease progression but for linearization of AUDPC following the two models (logit and gompit) showed that logit fit better than gompit for the prediction of tomato leaf curl virus and this was confirmed by the low standard error estimate (MSE) of logit in most of the treatments. The co-efficient of determination value (R2) showed that variation in disease severity can be explained up to88.5\% (maximum) in logistic as well as $98.7 \%$ (maximum) in Gompertz with combined effect of the weather variables included in the present study. The result also suggested with delay in planting time the disease severity (AUDPC) increases. Minimum disease severity (AUDPC) observed between planting time 16th August to 31st August. So, in West Bengal condition planting of tomato between these periods may be recommended with an expectation of minimum disease severity (AUDPC). 


\section{Introduction}

Tomato (Lycopersicon esculentum Mill.) is the second largest most widely grown vegetable crops grown all over the world. In India tomato is cultivated in Panjab, Haryana, Uttar Pradesh, Maharashtra, Karnataka and West Bengal. West Bengal is one of the leading producers of tomato. It is enriched with vitamins $A$ and $C$ as well as rich source of minerals and organic acids. Tomato cultivation has become increasingly popular among the small and marginal farmers' because of its varied climatic tolerance and able to fetch handsome amount of money.

Tomato is affected by large number of viral diseases. Among all the diseases reported, tomato leaf curl virus (ToLCV), a geminivirus (Geminiviridae: subgroup - III) is the most important and destructive viral pathogen in many parts of India (Vasudeva and Samraj, 1948: Sastry and Singh, 1973; Saikia and Muniyappa, 1989; Harrison et al., 1991) including West Bengal.

The disease is characterized by the curling and twisting of leaves followed by marked reduction in leaf size. The diseased plants look pale and stunted due to shortening of internodal length with more lateral branches resulting in a bushy appearance (Vasudeva and Sam Raj, 1948) and transmitted by whitefly Bemisia tabaci (Gennadius) (Homoptera: Aleyrodidae) (Vasudeva and Sam Raj, 1948; Butter and Rataul, 1973; Muniyappa and Veeresh, 1984).

Yield loss due to ToLCV has been reported $50-70 \%$ depending upon the growing season (Saikia and Muniyappa, 1989). Yield loss exceeds 90 per cent, when infection occurred within four weeks after transplanting in the field (Sastry and Singh, 1973; Saikia and Muniyappa, 1989). In many cases ToLCV epidemics lead to abandonment of the crop, particularly in seasons/periods favoring whitefly population build up (Pico et al., 1996).

For the last few years it appeared in epidemic form in different part of the country and facing the heavy toll to tomato. The reason identified injurious strains of $B$. tabaci are very difficult to manage, chemicals are the only weapon to control the vectors, having wide host range and continuous and overlapping cultivation of tomato throughout the year, its being very difficult to manage the disease. So, the present research programme is aimed to develop an economic management technique. To achieve the objective, the crop was planted at different planting dates to find the incidence of ToLCV encountering different environmental situations, as environment play an important role in the population dynamics of the whitefly and with the increase of the vector population disease incidence also assumed to increase. Several scientists Pruthi and Samuel (1942); Varma (1959); Saklani and Mathai (1977) and Ramos et al., (2002) and had recorded the month wise vector populations. There was a report by Shaheen (1983) revealed, early sown tomato in February was seldom infested, but that sown in April became severely infested throughout the flowering and fruiting stage resulting in 40 per cent crop loss.

Severe infestation at the seedling stage resulted in complete yield loss on autumn crops sown in August. B. tabaci attacking tomato in April-November with infestation peak in August-October. This fact helps to ponder over that variation in disease severity in different month due to changing environmental parameter in the field. So, the experiment was set to find out the most suitable date for planting of tomato considering its relationship with the prevailing meteorological parameters. Tomato 
plant can be grown through out the year but the severity of the disease varies during different years possibly as a result of changing environmental parameter. Therefore, it is better to determine the nature of relationship between the disease severity and the weather parameters (depicted through different dates of planting in this study) to verify the linearity of disease progress in simulation studies.

Linearization of disease progress curve is essential to determine the rate of epidemic, project future disease development and estimated initial disease severity. For the disease ToLCV in tomato, for linearization suitable amenable used through suitable transformation (Mayee and Datar, 1986). Here, two transformation equations were used for devising linearized mathematical models, viz., logistic (Van der Plank, 1963) and gompertz (Berger, 1981).

In this experiment, efforts put forth to determine the influence of different weather factors that act as a predisposing factor for the development of vector population of the disease and to formulate suitable prediction equations through step down multiple regression analysis of disease severity data from different dates of planting considering two different transformation models which ultimately aim to develop suitable economic management techniques through the choice of right time of planting on the basis of predicted disease severity involving the prevailing weather parameters.

\section{Materials and Methods}

Investigation was carried out at the University Farm Kalyani, Bidhan Chandra Krishi Viswavidyalaya, Nadia, West Bengal, during 2012-13 and 2013-14. The soil of the farm was sandy loam in texture (sand $52.74 \%$, silt $19.60 \%$ and clay $25.66 \%$ ) and belongs to the hyperthermic family with the $\mathrm{pH}$ 7.2. One susceptible tomato variety "Patharkuchi" (indeterminate type) was chosen and the field experiment was laid out at randomized block design (RBD) using 10 treatments (different dates of planting) in three replications, and the plot size was $5 \times 5 \mathrm{sq} \mathrm{m}$. Tomato seedlings of 30 days old were planted in each experimental plot at a spacing of $60 \mathrm{~cm} \times 30$ $\mathrm{cm}$. All recommended agronomic practices followed and natural epiphytotic was considered.

\section{Treatment details}

The seedlings were transplanted in the main field starting from $16^{\text {th }}$ August and at every 15 days interval and transplanting was done till $29^{\text {th }}$ December and the same was followed for the two consecutive experimental years.

Dates of transplanting were maintained same for both the experimental years i.e 2012-13 and 2013-14

\begin{tabular}{|l|l|}
\hline \multicolumn{2}{|c|}{ Dates of transplanting in the main field } \\
\hline D1 & $16-08-2012$ and $16-08-2013$ \\
\hline D2 & $31-08-2012$ and $31-08-2013$ \\
\hline D3 & $15-09-2012$ and $15-09-2013$ \\
\hline D4 & $30-09-2012$ and $30-09-2013$ \\
\hline D5 & $15-10-2012$ and $15-10-2013$ \\
\hline D6 & $30-10-2012$ and 30-10-2013 \\
\hline D7 & $14-11-2012$ and $14-11-2013$ \\
\hline D8 & $29-11-2012$ and $29-11-2013$ \\
\hline D9 & $14-12-2012$ and 14-12-2013 \\
\hline D10 & $29-12-2012$ and $29-12-2013$ \\
\hline
\end{tabular}

Validation of the pathogenicity of the pathogen

The diseased sample was collected from the field and sent to the Division of Plant Virology, IARI, New Delhi for identification of the pathogen and it was confirmed that the pathogen was Tomato leaf curl virus and its pathogenicity was proved artificially. 


\section{Disease scoring}

Percentage of infection in each plot, the number of leaf curl infected plants was noted by visual observation.

The number of leaf curl infected plants in each plot, was observed on $15^{\text {th }}, 30^{\text {th }}, 45^{\text {th }}$, $60^{\text {th }}, 75^{\text {th }}$ and $90^{\text {th }}$ days after transplanting.

The severity of the disease was measured on the basis of scale as follows (Friedmann et al., 1998)

\begin{tabular}{|l|l|}
\hline Scale & Description \\
\hline $\mathbf{0}$ & No visible symptom \\
\hline $\mathbf{1}$ & $\begin{array}{l}\text { Very slight yellowing of leaflet \& } \\
\text { margin on apical leaf }\end{array}$ \\
\hline $\mathbf{3}$ & $\begin{array}{l}\text { some yellowing \& minor curling of } \\
\text { leaflet ends }\end{array}$ \\
\hline $\mathbf{5}$ & $\begin{array}{l}\text { A wide range of yellowing curling } \\
\text { \& cupping of, reduction of leaf } \\
\text { size, plant continues to develop }\end{array}$ \\
\hline $\mathbf{7}$ & $\begin{array}{l}\text { Very severe plant stunting \& } \\
\text { yellowing }\end{array}$ \\
\hline $\mathbf{9}$ & $\begin{array}{l}\text { Pronounced leaf cupping \&curling, } \\
\text { plant growth stops }\end{array}$ \\
\hline
\end{tabular}

PDI was computed using the following formula:

$\begin{array}{lc}\text { Percent } & \begin{array}{l}\text { Sum of all numerical } \\ \text { ratings }\end{array} \\ \begin{array}{l}\text { Disease } \\ (\text { PDI })=\end{array} & \begin{array}{l}\text { Total number of leaf } \\ \text { observed } x \text { maximum } \\ \text { rating }\end{array}\end{array}$

Then the disease severity records were averaged over the three replications and disease progress curves were plotted. For each replication the area under disease progress curves was calculated as per Wilcoxon et al., (1975). The formula was used and follows:

$$
\underset{i=1}{\operatorname{AUDPC}=} \sum_{\mathrm{i}=1}\left[\left(\mathrm{Y}_{\mathrm{i}+1}+\mathrm{y}_{\mathrm{i}}\right) / 2\left(\mathrm{X}_{\mathrm{i}+1}-\mathrm{X}_{\mathrm{i}}\right)\right]
$$

$\mathrm{Y}_{\mathrm{i}}=$ severity at $1^{\text {st }}$ observation,

$\mathrm{X}_{\mathrm{i}}=$ Time (days) at first observation

$\mathrm{N}=$ Total number of observation

\section{Transformation models used under study}

The data obtained were subjected to both Gompertz (Kranz, 1974; Berger, 1981) and logistic transformation (Vander Plank 1963) using the following equation:

Logistic $=\operatorname{Logit}(\mathrm{Y})=\ln [\mathrm{Y} / 1-\mathrm{Y})]$

Gompertz $=$ gompit $(\mathrm{y})=-\ln [-\ln (\mathrm{y})]$

Where $\mathrm{Y}=$ Proportion of disease tissue.

Apparent infection rate calculated either as logistic infection rate (r) or gempertz infection rate $(k)$, for each increment of time determined using the respective formulae:

$\mathrm{dx} / \mathrm{dt}=\mathrm{Xr}(1-\mathrm{x})$ in case of polycyclic pathogen, Vander Plank (1963)

$\mathrm{X}=$ the proportion of tissue diseased

$\mathrm{r}=$ apparent infection rate,

$(1-x)=$ the proportion of tissue available for infection, exp. In $=$ Logarithms (to the base e).

If the total amount of " $X$ " of capital interest varies with time ' $t$ ', then $d t$ means a very small interval of time and $d x$ is the very small bit that $\mathrm{X}$ increase in that interval.

a. $\mathrm{k}, \mathrm{c}, \mathrm{b}$ and $0.05=$ constant

The best fit of a specific model to the data was determined by comparison of the rate parameters (' $r$ ' for logistic and ' $k$ ' for Gompertz), which is nothing but the regression coefficient ' $b$ ', y-intercept (a).

\section{Weather parameters and statistical analysis}

The available meteorological data on weather variables viz. maximum temperature ( $\mathrm{T}$ max) 
and minimum temperature ( $\mathrm{T}$ min) and their differences (Tmax-Tmin), maximum (RH $\max$ ) and minimum relative humidity (RHmin) and rainfall (R)were collected from AICRP on Agro-Meteorology, Bidhan Chandra Krishi Viswavidyalaya, Kalyani, West Bengal. Seven days mean of those weather parameter (variables) were recorded at morning (06.35) except for the seven days cumulative rainfall and the number of rainy days for the entire period of disease assessment were worked out.

To predict the disease development, multiple regression equations were computed by using SPSS computer software. Coefficient of determination $\left(\mathrm{R}^{2}\right)$ was also calculated and tested for significance at $1 \%$ level of probability. Disease prediction models were developed using the following equation:

$\mathrm{Y}(\mathrm{PDI})=\mathrm{a}+\mathrm{b}_{\mathrm{i}} \mathrm{X}_{\mathrm{i}}+\mathrm{e}$

Where, $Y=$ predicted disease index; $a=$ intercept; $b_{i}=$ regression coefficient for $X_{i}(i=$ n) and $X_{i}=$ independent variable $(i=1 \mathrm{n}$ i.e weather parameters); $\mathrm{e}=$ random error.

Step down multiple regression analysis was applied to disease severity data. The goodness of fit to the model so obtained was evaluated by co-efficient determination $\left(\mathrm{R}^{2}\right)$; adjusted determination of co-efficient $\left(R^{2}\right.$ adj) and error means square (MSE). So, a final evaluation of the model was determined based on the above three criteria (Berenson et al 1983, Coakley et al., 1988).

\section{Results and Discussion}

Tomato variety 'Patharkunchi' was used in this experiment and 30 days old seedlings were planted in 10 different date starting from $16^{\text {th }}$ august to $29^{\text {th }}$ December at 15 days interval in two consecutive years i.e 2012-13 and 2013-14 to find out the suitable date of planting for minimum disease severity.
The results indicated that, lowest disease severity was found when tomato was planted in $\left(\mathrm{D}_{1=} 16^{\text {th }}\right.$ August) (AUDPC $\left.=94.08\right)$ and (AUDPC: 97.01) respectively for the year 2012-13 and 2013-14 (Table 1 and 2). Followed by $\left(\mathrm{D}_{2=}=31^{\mathrm{st}}\right.$ August) (AUDPC= 95.02 and $A U D P C=97.80$ ) in both the experimental year correspondingly (Table 1 and 2). The disease severity started to increase from the next dates of planting and found maximum at $\left(\mathrm{D}_{4}=30^{\text {th }}\right.$ September $)$ (AUDPC $=101.91$ ). After that the disease severity started to reduce from the (D5 $=15$ th October) (AUDPC $=99.84$ ) and continued upto $(\mathrm{D} 10=29$ th December) (AUDPC = 95.13) (Table 1).

Similar trend is followed in the progression of disease over the year 2013-14. Here, also maximum disease severity observed in (D4 = $30^{\text {th }}$ September: AUDPC $\left.=102.66\right)$ followed by $\left(\mathrm{D} 5=15^{\text {th }}\right.$ October: AUDPC $\left.=101.30\right)$ and D6 $=30^{\text {th }}$ October: AUDPC $\left.=101.05\right)($ Table 2).

Sakalani and Mathai (1977), reported that October to mid December was the most effective time for planting tomato followed by January to first March in Pantnagar (UP). In March to September sown crop ToLCV appeared within 25 to 45 days after planting whereas appearance of ToLCV symptom was delayed when the crop was sown during October to mid December.

Our finding also in agreement to the result revealed by Mahajan (2001), where $1^{\text {st }}$ September planting was found to be suitable to get the stable yield from tomato with minimum infection by ToLCV. In later dates of planting, though recorded less disease incidence but produce lower yield.

Less incidence on later transplanted and more incidence on early transplanted tomato crops during autumn season have been reported by 
many workers including Saikia and Muniyappa (1989), Polizzi et al., (1994); Borah and Bordoloi (1998) in also in support with the findings in the present study.

The AUDPC data obtained was subjected to both gompertz and logistic transformation and equations were developed and presented in Table 1 and 2. Both the transformation models showed the mode of spread of the disease over time (Fig. 1) and provide a comparative study through which the scientists could depict which model suits better to describe the spread of the disease. Our results presented in Tables 1 and 2 concluded that both the model can fit to depict the disease progression over time but lower standard errors of logit model suggested that logit fit better than gompitin case of tomato leaf curl virus. Among the gompit transformation, it was best fit in D1 $\left(16^{\text {th }}\right.$ August) and D2 (31 August) planting with $(a=6.713$ and $14.279 b=0.021$ and $0.015 c$ $=0.850$ and 0.884 with MSE value $=0.004$ and 0.002) in the year 2012-13 and 201314respectively for D1.Similar trends followed by D2 (31 ${ }^{\text {st }}$ August) and D5 (15 October) planting in both the year. But for the rest of the treatments low MSE value of logit proved that it suits better to predict the disease progression than high MSE value of gompit.

Plant disease development is a dynamic process and depends upon the interactions between the host, pathogen and the environment. Here, one more factor is included i.e the vector. The variation in any one of the factor influence the disease development. Here, environmental variation was considered as an independent variable in the regression equation to develop prediction equations over the two experimental years and both the model logit and gompit was considered to linearize the disease progress curves. Depending upon the nature of the disease progress curves, one model found fit better than the other into a specific plant pathosystem.

\section{Prediction equations}

In this experiment, six independent variables i.e $\mathrm{T}$ max, $\mathrm{T}$ min, Tmax-min, $\mathrm{RH} \max , \mathrm{RH}$ min (average taken and represented as only $\mathrm{RH})$ and total rainfall (RF) were considered and their influence on the disease development were established through the development of prediction equations and the procedure followed was step down multiple regression analysis.

The result revealed that there was a positive significant correlation between the disease severity and $\mathrm{T}$ mean and mean $\mathrm{RH}$ and total rainfall with the progression of the disease through AUDPC following the two different models tested and it remain true for all the treatments in the following year experiment also. In this situation, the only way to determine the best fit model is the comparison between low standard error of the estimate (MSE) table 3 and 4.

In the year, 2012-13 treatment D1 $\left(16^{\text {th }}\right.$ August), D2 (31 ${ }^{\text {st }}$ August), and D5 (15 ${ }^{\text {th }}$ October) Gompertz model showed low MSE value than logit, so, progression of the disease in this dates of planting they can be best explained through gompit model and for the rest of the treatments logit model was found better (Table 3 and Fig. 1).

During 2013-14, predicted disease index following logit model showing same pattern as the previous year. Differences observed in case of D1 (16 $6^{\text {th }}$ August), D2 (31 ${ }^{\text {st }}$ August), and D5 $\left(15^{\text {th }}\right.$ October) where gompit model suits best to describe disease progression (Table 4). From the data presented in the table 3 and 4 representing the respective experimental year conclude that among the environmental variable tested $\mathrm{T}$ mean, $\mathrm{RH}$ 
and rainfall all are positively and significantly correlated with disease severity.

Several workers worked on the relationship between the weather parameters and severity of ToLCV, whose report supports our observation. Singh et al., (1999) who reported that spread of the disease was rapid with the maximum temperature of 28.7 to $30.8{ }^{\circ} \mathrm{C}$ and minimum temperature of $15.1-22.3{ }^{0} \mathrm{C}, 2.0$ $\mathrm{mm}$ rainfall and maximum minimum relative humidity of 88-91.30 and 44.6 - 69.6 per cent, respectively.

Yassin (1975) reported the negative correlation between ToLCV incidence and wind direction. Nitzany (1975) testified relationship between $\mathrm{RH}$ and ToLCV outbreak and concluded most favourable is $\mathrm{T}$ mean $30^{\circ} \mathrm{C}$ and $\mathrm{RH}<60 \%$ but (Makkouk et $a l .$, 1979) reported ToLCV outbreaks in the coastal region with a mean relative humidity more than 60 per cent. Similar type of experiment conducted by Saha and Das (2014) on chemical management of tomato early blight contradicts our result in terms of disease progression where gompit was found to fit better in the expression of disease progress curve.

From the above equations and the literature cited it is observed that, $\mathrm{T}$ mean, mean $\mathrm{RH}$ and rainfall are related positively and significantly with the disease severity in both the year and plays the major role in both the year. But for more precise conclusion further study has been needed considering few more factors like wind velocity, Bright sunshine hour, mean cloudiness etc. those may have direct or indirect effect on either vector population or on the host, major components of the phyto epidemics.

Coefficient of determination $\left(\mathrm{R}^{2}\right)$ value indicated that the predicted value of PDI can be explained 35.8 percent to 88.5 percent of the total variation in the PDI in case logit transformation scale and Gompit exhibit 51.3 percent to 98.7 percent variation in the prediction of disease severity in the year 2012-13. In 2013-14, this variation was from 62.3 percent to 86.7 percent under logit and 63.6 percent to 86.9 percent under Gompit respectively.

Table.1 Distribution of tomato leaf curl disease on tomato subjecting to logit and Gompit transformation at different dates of planting during 2012-13

\begin{tabular}{|l|c|c|c|c|l|l|l|l|l|}
\hline Treatments & AUDPC & \multicolumn{4}{|c|}{ Logit transformation value } & \multicolumn{3}{c|}{ Gompit transformation value } \\
\hline & $2012-13$ & $\mathrm{k}$ & $\mathrm{a}$ & $\mathrm{b}$ & MSE & $\mathrm{a}$ & $\mathrm{b}$ & $\mathrm{c}$ & $\mathrm{MSE}$ \\
\hline $\mathbf{D}_{\mathbf{1}}$ & 94.08 & 2.312 & 3.091 & $(-) 0.526$ & 0.005 & 6.713 & 0.021 & 0.850 & 0.004 \\
\hline $\mathbf{D}_{\mathbf{2}}$ & 95.02 & 2.719 & 2.984 & $(-) 0.522$ & 0.003 & 5.453 & 0.032 & 0.822 & 0.001 \\
\hline $\mathbf{D}_{\mathbf{3}}$ & 96.28 & 2.782 & 2.498 & $(-) 0.496$ & 0.003 & 8.213 & 0.040 & 0.864 & 0.003 \\
\hline $\mathbf{D}_{\mathbf{4}}$ & 101.91 & 4.432 & 3.462 & $(-) 0.866$ & 0.001 & 7.023 & 0.037 & 0.710 & 0.004 \\
\hline $\mathbf{D}_{\mathbf{5}}$ & 99.84 & 4.553 & 3.461 & $(-) 0.731$ & 0.006 & 10.885 & 0.022 & 0.791 & 0.003 \\
\hline $\mathbf{D}_{\mathbf{6}}$ & 99.30 & 3.665 & 3.451 & $(-) 0.813$ & 0.003 & 8.093 & 0.031 & 0.775 & 0.014 \\
\hline $\mathbf{D}_{\mathbf{7}}$ & 98.02 & 3.077 & 3.667 & $(-) 0.884$ & 0.005 & 5.627 & 0.029 & 0.733 & 0.013 \\
\hline $\mathbf{D}_{\mathbf{8}}$ & 96.31 & 6.317 & 3.912 & $(-) 0.540$ & 0.003 & 5.602 & 0.014 & 0.977 & 0.018 \\
\hline $\mathbf{D}_{\mathbf{9}}$ & 94.91 & 2.112 & 3.166 & $(-) 0.661$ & 0.002 & 3.122 & 0.038 & 0.751 & 0.002 \\
\hline $\mathbf{D}_{\mathbf{1 0}}$ & 95.13 & 2.391 & 3.679 & $(-) 0.750$ & 0.001 & 7.188 & 0.015 & 0.805 & 0.047 \\
\hline
\end{tabular}

$\mathrm{AUDPC}=$ Area Under Disease Progress Curve, MSE $=$ Error mean square $\mathrm{D}_{1}=16^{\text {th }}$ August planting. $\mathrm{D}_{2}=31^{\text {st }}$ August planting, $\mathrm{D}_{3}=15^{\text {th }}$ September planting, $\mathrm{D}_{4}=30^{\text {th }}$ September planting, $\mathrm{D}_{5}=15^{\text {th }}$ October planting, $\mathrm{D}_{6}=30^{\text {th }}$ October planting $\mathrm{D}_{7}=14^{\text {th }}$

November planting, $\mathrm{D}_{8}=29^{\text {th }}$ November planting, $\mathrm{D}_{9}=14^{\text {th }}$ December planting, $\mathrm{D}_{10}=29^{\text {th }}$ December planting 
Table.2 Distribution of tomato leaf curl disease on tomato subjecting to logit and gompit transformation at different dates of planting during 2013-14

\begin{tabular}{|l|c|l|l|l|l|l|l|l|l|}
\hline Treatments & AUDPC & \multicolumn{4}{|c|}{ Logit transformation value } & \multicolumn{3}{c|}{ Gompit transformation value } \\
\hline & $2013-14$ & $\mathrm{~K}$ & $\mathrm{a}$ & $\mathrm{b}$ & $\mathrm{MSE}$ & $\mathrm{a}$ & $\mathrm{b}$ & $\mathrm{c}$ & MSE \\
\hline $\mathbf{D}_{\mathbf{1}}$ & 97.01 & 9.076 & 6.285 & $(-) 0.363$ & 0.009 & 14.279 & 0.015 & 0.884 & 0.002 \\
\hline $\mathbf{D}_{\mathbf{2}}$ & 97.80 & 2.983 & 2.566 & $(-) 0.435$ & 0.003 & 4.803 & 0.062 & 0.840 & 0.002 \\
\hline $\mathbf{D}_{\mathbf{3}}$ & 99.12 & 1.743 & 2.225 & $(-) 0.752$ & 0.001 & 2.172 & 0.169 & 0.709 & 0.010 \\
\hline $\mathbf{D}_{\mathbf{4}}$ & 102.66 & 3.502 & 2.784 & $(-) 0.650$ & 0.002 & 5.619 & 0.063 & 0.772 & 0.005 \\
\hline $\mathbf{D}_{\mathbf{5}}$ & 101.30 & 3.774 & 2.566 & $(-) 0.563$ & 0.005 & 5.068 & 0.065 & 0.749 & 0.002 \\
\hline $\mathbf{D}_{\mathbf{6}}$ & 101.05 & 9.910 & 3.828 & $(-) 0.410$ & 0.002 & 9.683 & 0.023 & 0.852 & 0.003 \\
\hline $\mathbf{D}_{\mathbf{7}}$ & 99.99 & 3.681 & 3.293 & $(-) 0.492$ & 0.007 & 5.947 & 0.030 & 0.834 & 0.012 \\
\hline $\mathbf{D}_{\mathbf{8}}$ & 98.78 & 2.223 & 2.449 & $(-) 0.479$ & 0.004 & 3.506 & 0.067 & 0.811 & 0.015 \\
\hline $\mathbf{D}_{\mathbf{9}}$ & 97.63 & 1.837 & 2.660 & $(-) 0.541$ & 0.004 & 5.056 & 0.031 & 0.850 & 0.006 \\
\hline $\mathbf{D}_{\mathbf{1 0}}$ & 97.76 & 1.438 & 3.064 & $(-) 0.674$ & 0.007 & 1.665 & 0.059 & 0.709 & 0.026 \\
\hline
\end{tabular}

AUDPC $=$ Area Under Disease Progress Curve, MSE $=$ Error mean square $\mathrm{D}_{1}=16^{\text {th }}$ August planting. $\mathrm{D}_{2}=31^{\text {st }}$ August planting, $\mathrm{D}_{3}=15^{\text {th }}$ September planting, $\mathrm{D}_{4}=30^{\text {th }}$ September planting, $\mathrm{D}_{5}=15^{\text {th }}$ October planting, $\mathrm{D}_{6}=30^{\text {th }}$ October planting $\mathrm{D}_{7}=14^{\text {th }}$ November planting, $\mathrm{D}_{8}=29^{\text {th }}$ November planting, $\mathrm{D}_{9}=14^{\text {th }}$ December planting, $\mathrm{D}_{10}=29^{\text {th }}$ December planting

Table.3 Step down multiple regression analysis for developing prediction equations depicted from logistic and gompertz transformation of tomato leaf curl disease on tomato at different dates of planting in relation to weather parameter recorded during 2012-13

\begin{tabular}{|c|c|c|c|c|}
\hline $\begin{array}{l}\text { Treat } \\
\text { ments }\end{array}$ & Regression equation & $\begin{array}{l}\text { Coefficient of } \\
\text { determination } \\
\left(\mathbf{R}^{2}\right)\end{array}$ & $\begin{array}{l}\text { Adjust } \\
\text { ed }\left(R^{2}\right)\end{array}$ & $\begin{array}{l}\text { Std. } \text { Error } \\
\text { of the } \\
\text { estimate }\end{array}$ \\
\hline $\mathbf{D}_{1}$ & $\begin{array}{l}(\mathrm{L}) \rightarrow \dot{\mathrm{Y}}=-0.797+0.804 \mathrm{~T}_{\text {mean }}+0.674 \mathrm{RF}+0.681 \mathrm{RH} \\
(\mathrm{G}) \rightarrow \dot{\mathrm{Y}}=-0.771+0.793 \mathrm{~T}_{\text {mean }}+0.537 \mathrm{RF}+0.445 \mathrm{RH}\end{array}$ & $\begin{array}{l}0.854 * * \\
0.918 * *\end{array}$ & $\begin{array}{l}0.776 \\
0.843\end{array}$ & $\begin{array}{l}0.465 \\
0.218\end{array}$ \\
\hline $\mathbf{D}_{2}$ & $\begin{array}{l}(\mathrm{L}) \rightarrow \grave{Y}=-0.995+0.932 \mathrm{~T}_{\text {mean }}+0.659 \mathrm{RF}+0.930 \mathrm{RH} \\
(\mathrm{G}) \rightarrow \grave{Y}=-0.8975+0.914 \mathrm{~T}_{\text {mean }}+0.532 \mathrm{RF}+0.876 \mathrm{RH}\end{array}$ & $\begin{array}{l}0.358 \\
0.794 *\end{array}$ & $\begin{array}{l}0.348 \\
0.737\end{array}$ & $\begin{array}{l}0.378 \\
0.167\end{array}$ \\
\hline $\mathbf{D}_{3}$ & $\begin{array}{l}(\mathrm{L}) \rightarrow \dot{\mathrm{Y}}=0.455+0.752 \mathrm{~T}_{\text {mean }}+0.790 \mathrm{RF}+0.495 \mathrm{RH} \\
(\mathrm{G}) \rightarrow \dot{\mathrm{Y}}=-0.394+0.646 \mathrm{~T}_{\text {mean }}+0.630 \mathrm{RF}+0.564 \mathrm{RH}\end{array}$ & $\begin{array}{l}0.478 \\
0.548\end{array}$ & $\begin{array}{l}0.426 \\
0.537\end{array}$ & $\begin{array}{l}0.366 \\
0.356\end{array}$ \\
\hline $\mathbf{D}_{4}$ & $\begin{array}{l}(\mathrm{L}) \rightarrow \dot{\mathrm{Y}}=-0.951+0.077 \mathrm{~T}_{\text {mean }}+0.567 \mathrm{RF}+0.480 \mathrm{RH} \\
(\mathrm{G}) \rightarrow \dot{\mathrm{Y}}=-0.956+0.718 \mathrm{~T}_{\text {mean }}+0.852 \mathrm{RF}+0.952 \mathrm{RH}\end{array}$ & $\begin{array}{l}0.883^{* *} \\
0.587\end{array}$ & $\begin{array}{l}0.301 \\
0.609\end{array}$ & $\begin{array}{l}0.256 \\
0.478\end{array}$ \\
\hline $\mathbf{D}_{5}$ & $\begin{array}{l}(\mathrm{L}) \rightarrow \grave{Y}=-0.759+0.797 \mathrm{~T}_{\text {mean }}+0.868 \mathrm{RF}+0.647 \mathrm{RH} \\
(\mathrm{G}) \rightarrow \grave{Y}=-0.828+0.520 \mathrm{~T}_{\text {mean }}+0.669 \mathrm{RF}+0.548 \mathrm{RH}\end{array}$ & $\begin{array}{l}0.658 \\
0.757 *\end{array}$ & $\begin{array}{l}0.439 \\
0.578\end{array}$ & $\begin{array}{l}0.477 \\
0.203\end{array}$ \\
\hline$D_{6}$ & $\begin{array}{l}(\mathrm{L}) \rightarrow \dot{Y}=-0.775+0.567 \mathrm{~T}_{\text {mean }}+0.845 R F+0.567 \mathrm{RH} \\
(\mathrm{G}) \rightarrow \dot{\mathrm{Y}}=-0.665+0.685 \mathrm{~T}_{\text {mean }}+0.348 R F+0.607 \mathrm{RH}\end{array}$ & $\begin{array}{l}0.866 * * \\
0.987 * *\end{array}$ & $\begin{array}{l}0.765 \\
0.890\end{array}$ & $\begin{array}{l}0.657 \\
0.765\end{array}$ \\
\hline $\mathbf{D}_{7}$ & $\begin{array}{l}(\mathrm{L}) \rightarrow \dot{\mathrm{Y}}=-0.876+0.465 \mathrm{~T}_{\text {mean }}+0.898 \mathrm{RF}+0.647 \mathrm{RH} \\
(\mathrm{G}) \rightarrow \dot{\mathrm{Y}}=-0.715+0.875 \mathrm{~T}_{\text {mea }}+0.678 R F+0.567 \mathrm{RH}\end{array}$ & $\begin{array}{l}0.782^{*} \\
0.513\end{array}$ & $\begin{array}{l}0.675 \\
0.399\end{array}$ & $\begin{array}{l}0.246 \\
0.477\end{array}$ \\
\hline $\mathbf{D}_{8}$ & $\begin{array}{l}(\mathrm{L}) \rightarrow \grave{Y}=-0.845++0.374 \mathrm{~T}_{\text {mean }}+0.492 \mathrm{RF}+0.004 \mathrm{RH} \\
(\mathrm{G}) \rightarrow \grave{Y}=-0.059+0.346 \mathrm{~T}_{\text {mean }}+0.574 \mathrm{RF}+0.176 \mathrm{RH}\end{array}$ & $\begin{array}{l}0.885^{* *} \\
0.740^{*}\end{array}$ & $\begin{array}{l}0.788 \\
0.695\end{array}$ & $\begin{array}{l}0.493 \\
0.674\end{array}$ \\
\hline $\mathbf{D}_{9}$ & $\begin{array}{l}(\mathrm{L}) \rightarrow \dot{Y}=-0.894+0.678 \mathrm{~T}_{\text {mean }}+0.307 R F+0.469 \mathrm{RH} \\
(\mathrm{G}) \rightarrow \dot{\mathrm{Y}}=-0.769+0.657 \mathrm{~T}_{\text {mean }}+0.678 R F+0.147 \mathrm{RH}\end{array}$ & $\begin{array}{l}0.848^{* *} \\
0.769 *\end{array}$ & $\begin{array}{l}0.754 \\
0.583\end{array}$ & $\begin{array}{l}0.224 \\
0.228\end{array}$ \\
\hline $\mathbf{D}_{10}$ & $\begin{array}{l}(\mathrm{L}) \rightarrow \dot{\mathrm{Y}}=-0.768+0.387 \mathrm{~T}_{\text {mean }}+0.748 \mathrm{RF}+0.289 \mathrm{RH} \\
(\mathrm{G}) \rightarrow \dot{\mathrm{Y}}=-0.669+0.797 \mathrm{~T}_{\text {mean }}+0.467 \mathrm{RF}+0.379 \mathrm{RH}\end{array}$ & $\begin{array}{l}0.854 * * \\
0.713 *\end{array}$ & $\begin{array}{l}0.778 \\
0.684\end{array}$ & $\begin{array}{l}0.356 \\
0.567\end{array}$ \\
\hline
\end{tabular}

$\mathrm{L}=$ Prediction equation depicted from logistic transformation, $\mathrm{G}=$ Prediction equation depicted from gompertz transformation, $\mathrm{RH}=$ Relative humidity, $* *=$ Significant at $1 \%$ level of probability, $*=$ Significant at $5 \%$ level of probability $\mathrm{D}_{1}=16^{\text {th }}$ August planting. $\mathrm{D}_{2}=31^{\text {st }}$ August planting, $\mathrm{D}_{3}=15^{\text {th }}$ September planting, $\mathrm{D}_{4}=30^{\text {th }}$ September planting, $\mathrm{D}_{5}=15^{\text {th }}$ October planting, $\mathrm{D}_{6}=30^{\text {th }}$ October planting $D_{7}=14^{\text {th }}$ November planting, $D_{8}=29^{\text {th }}$ November planting, $D_{9}=14^{\text {th }}$ December planting, $D_{10}=29^{\text {th }}$ December planting 
Table.4 Step down multiple regression analysis for developing prediction equations depicted from logistic and gompertz transformation of tomato leaf curl disease on tomato at different dates of planting in relation to weather parameter recorded during 2013-14

\begin{tabular}{|c|c|c|c|c|}
\hline $\begin{array}{l}\text { Treat } \\
\text { ments }\end{array}$ & Regression equation & $\begin{array}{l}\text { Coefficient of } \\
\text { determination } \\
\left(\mathbf{R}^{2}\right)^{* *}\end{array}$ & $\begin{array}{l}\text { Adjusted } \\
\left(\mathbf{R}^{2}\right)\end{array}$ & $\begin{array}{l}\text { Std. } \\
\text { of thror } \\
\text { estimate }\end{array}$ \\
\hline$D_{1}$ & $\begin{array}{l}(\mathrm{L}) \rightarrow \grave{\mathrm{Y}}=-0.675+0.546 \mathrm{~T}_{\text {mean }}+0.478 \mathrm{RF}+0.086 \mathrm{RH} \\
(\mathrm{G}) \rightarrow \grave{\mathrm{Y}}=-0.589+0.475 \mathrm{~T}_{\text {mean }}+0.034 \mathrm{RH}+0.003 \mathrm{RH}\end{array}$ & $\begin{array}{l}0.695 \\
0.755^{*}\end{array}$ & $\begin{array}{l}0.527 \\
0.686\end{array}$ & $\begin{array}{l}0.047 \\
0.088\end{array}$ \\
\hline $\mathbf{D}_{2}$ & $\begin{array}{l}(\mathrm{L}) \rightarrow \grave{Y}=-0.456+0.675 \mathrm{~T}_{\text {mean }}+0.376 \mathrm{RF}+0.047 \mathrm{RH} \\
(\mathrm{G}) \rightarrow \grave{Y}=-0.568+0.567 \mathrm{~T}_{\text {mean }}+0.578 \mathrm{RF}+0.056 \mathrm{RH}\end{array}$ & $\begin{array}{l}0.636 \\
0.846^{* *}\end{array}$ & $\begin{array}{l}0.537 \\
0.567\end{array}$ & $\begin{array}{l}0.086 \\
0.079\end{array}$ \\
\hline $\mathbf{D}_{3}$ & $\begin{array}{l}(\mathrm{L}) \rightarrow \grave{\mathrm{Y}}=-0.567+0.675 \mathrm{~T}_{\text {mean }}+0.345 \mathrm{RF}+0.897 \mathrm{RH} \\
(\mathrm{G}) \rightarrow \grave{\mathrm{Y}}=-0.886+0.567 \mathrm{~T}_{\text {mean }}+0.098 \mathrm{RF}+0.265 \mathrm{RH}\end{array}$ & $\begin{array}{l}0.623 \\
0.869 * *\end{array}$ & $\begin{array}{l}0.512 \\
0.563\end{array}$ & $\begin{array}{l}0.026 \\
0.015\end{array}$ \\
\hline $\mathbf{D}_{4}$ & $\begin{array}{l}(\mathrm{L}) \rightarrow \grave{\mathrm{Y}}=-0.345+0.456 \mathrm{~T}_{\text {mean }}+0.479 \mathrm{RF}+0.548 \mathrm{RH} \\
(\mathrm{G}) \rightarrow=-0.453+0.398 \mathrm{~T}_{\text {mean }}+0.287 \mathrm{RF}+0.145 \mathrm{RH}\end{array}$ & $\begin{array}{l}0.854^{* *} \\
0.698\end{array}$ & $\begin{array}{l}0.721 \\
0.667\end{array}$ & $\begin{array}{l}0.254 \\
0.345\end{array}$ \\
\hline $\mathbf{D}_{5}$ & $\begin{array}{l}(\mathrm{L}) \rightarrow \grave{\mathrm{Y}}=-0.167+0.897 \mathrm{~T}_{\text {mean }}+0.790 \mathrm{RF}+0.134 \mathrm{RH} \\
(\mathrm{G}) \rightarrow \grave{\mathrm{Y}}=-0.452+0.768 \mathrm{~T}_{\text {mean }}+0.567 \mathrm{RF}+0.754 \mathrm{RH}\end{array}$ & $\begin{array}{l}0.687 \\
0.773^{*}\end{array}$ & $\begin{array}{l}0.576 \\
0.678\end{array}$ & $\begin{array}{l}0.142 \\
0.037\end{array}$ \\
\hline$D_{6}$ & $\begin{array}{l}(\mathrm{L}) \rightarrow \grave{\mathrm{Y}}=-0.342+0.303 \mathrm{~T}_{\text {mean }}+0.472 \mathrm{RF}+0.493 \mathrm{RH} \\
(\mathrm{G}) \rightarrow \grave{Y}=-0.267+0.483 \mathrm{~T}_{\text {mean }}+0.437 \mathrm{RF}+0.376 \mathrm{RH}\end{array}$ & $\begin{array}{l}0.863 * * \\
0.773^{*}\end{array}$ & $\begin{array}{l}0.673 \\
0.603\end{array}$ & 0.243 \\
\hline $\mathbf{D}_{7}$ & $\begin{array}{l}(\mathrm{L}) \rightarrow \grave{\mathrm{Y}}=-0.473+0.876 \mathrm{~T}_{\text {mean }}+0.365 \mathrm{RF}+0.504 \mathrm{RH} \\
(\mathrm{G}) \rightarrow \grave{\mathrm{Y}}=-0.493+0.456 \mathrm{~T}_{\text {mean }}+0.404 \mathrm{RF}+0.289 \mathrm{RH}\end{array}$ & $\begin{array}{l}0.753 * \\
0.641 * *\end{array}$ & $\begin{array}{l}0.639 \\
0.652\end{array}$ & $\begin{array}{l}0.187 \\
0.276\end{array}$ \\
\hline $\mathbf{D}_{8}$ & $\begin{array}{l}(\mathrm{L}) \rightarrow \grave{\mathrm{Y}}=-0.578+0.389 \mathrm{~T}_{\text {mean }}+0.487 \mathrm{RF}+0.010 \mathrm{RH} \\
(\mathrm{G}) \rightarrow \grave{\mathrm{Y}}=-0.678+0.393 \mathrm{~T}_{\text {mean }}+0.240 \mathrm{RF}+0.288 \mathrm{RH}\end{array}$ & $\begin{array}{l}0786^{*} \\
0.636\end{array}$ & $\begin{array}{l}0.609 \\
0.553\end{array}$ & $\begin{array}{l}0.036 \\
0.156\end{array}$ \\
\hline $\mathbf{D}_{9}$ & $\begin{array}{l}(\mathrm{L}) \rightarrow \grave{\mathrm{Y}}=-0.765+0.678 \mathrm{~T}_{\text {mean }}+0.358 \mathrm{RF}+0.987 \mathrm{RH} \\
(\mathrm{G}) \rightarrow \grave{Y}=-0.868+0.138 \mathrm{~T}_{\text {mean }}+0.584 \mathrm{RF}+0.596 \mathrm{RH}\end{array}$ & $\begin{array}{l}0.867 * * \\
0.676\end{array}$ & $\begin{array}{l}0.478 \\
0.367\end{array}$ & $\begin{array}{l}0.273 \\
0.392\end{array}$ \\
\hline$D_{10}$ & $\begin{array}{l}(\mathrm{L}) \rightarrow \grave{Y}=-0.384+0.567 \mathrm{~T}_{\text {mean }}+0.247 \mathrm{RF}+0.654 \mathrm{RH} \\
(\mathrm{G}) \rightarrow \grave{Y}=-0.370++0.456 \mathrm{~T}_{\text {mean }}+0.467 \mathrm{RF}+0.567 \mathrm{RH}\end{array}$ & $\begin{array}{l}0.787 * \\
0.676\end{array}$ & $\begin{array}{l}0.776 \\
0.568\end{array}$ & $\begin{array}{l}0.398 \\
0.465\end{array}$ \\
\hline
\end{tabular}

$\mathrm{L}=$ Prediction equation depicted from logistic transformation, $\mathrm{G}=$ Prediction equation depicted from gompertz transformation, $\mathrm{RH}=$ Relative humidity, $\mathrm{BSH}=$ Bright sunshine hour, $\mathrm{VP}=$ Vapour pressure, ${ }^{* *}=$ Significant at $1 \%$ level of probability, ${ }^{*}=$ Singnificant at $5 \%$ level of probability $\mathrm{D}_{1}=16^{\text {th }}$ August planting. $\mathrm{D}_{2}=31^{\text {st }}$ August planting, $\mathrm{D}_{3}=15^{\text {th }}$ September planting, $\mathrm{D}_{4}=30^{\text {th }}$ September planting, $\mathrm{D}_{5}=15^{\text {th }}$ October planting, $D_{6}=30^{\text {th }}$ October planting $D_{7}=14^{\text {th }}$ November planting, $D_{8}=29^{\text {th }}$ November planting, $D_{9}=14^{\text {th }}$ December planting, $D_{10}=$ $29^{\text {th }}$ December planting 
Fig.1 Comparison of observed and predicted disease progress curve under logistic and gompertz model on different dates of transplanting during 2012-13 and 2013-14
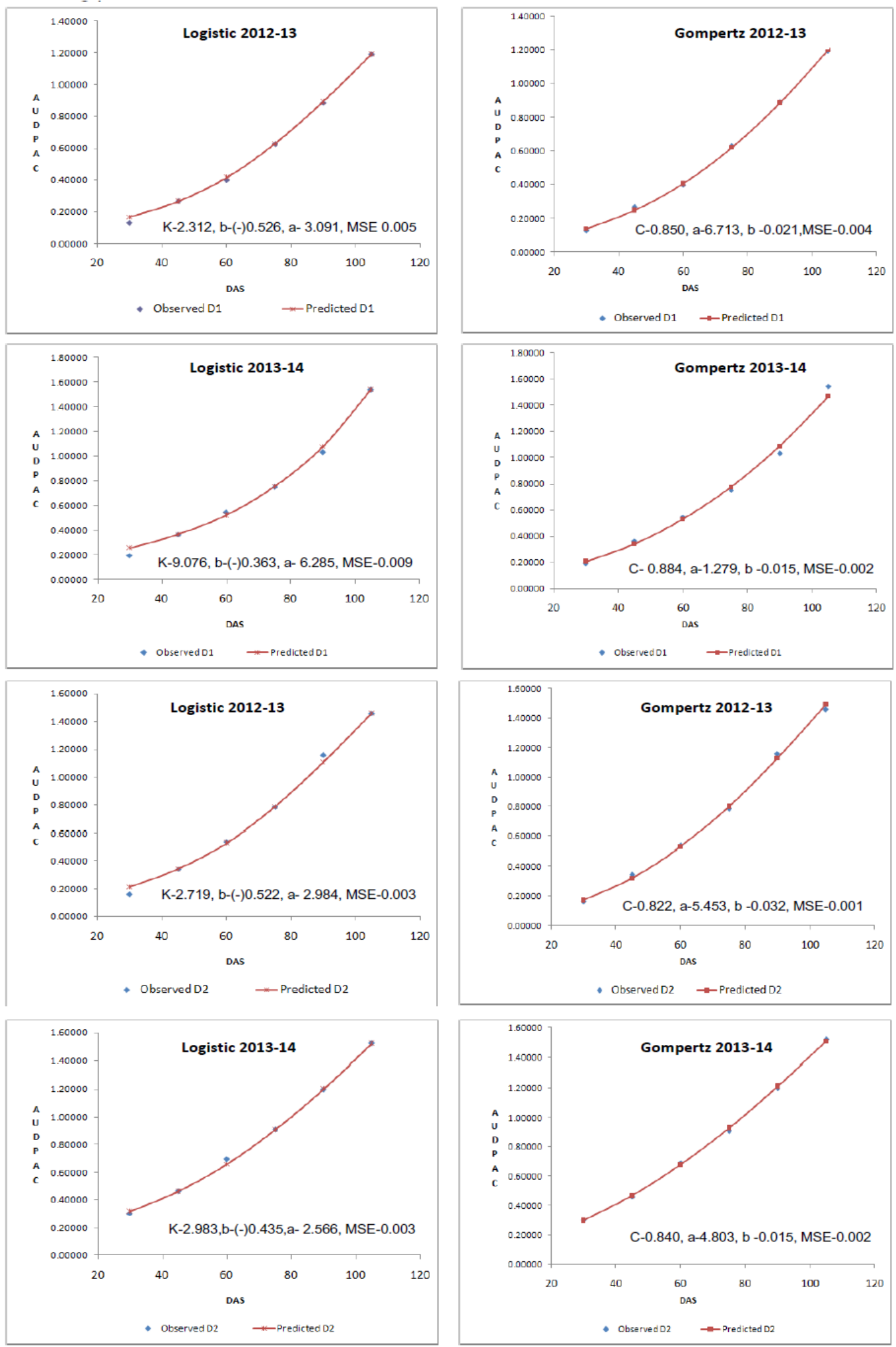

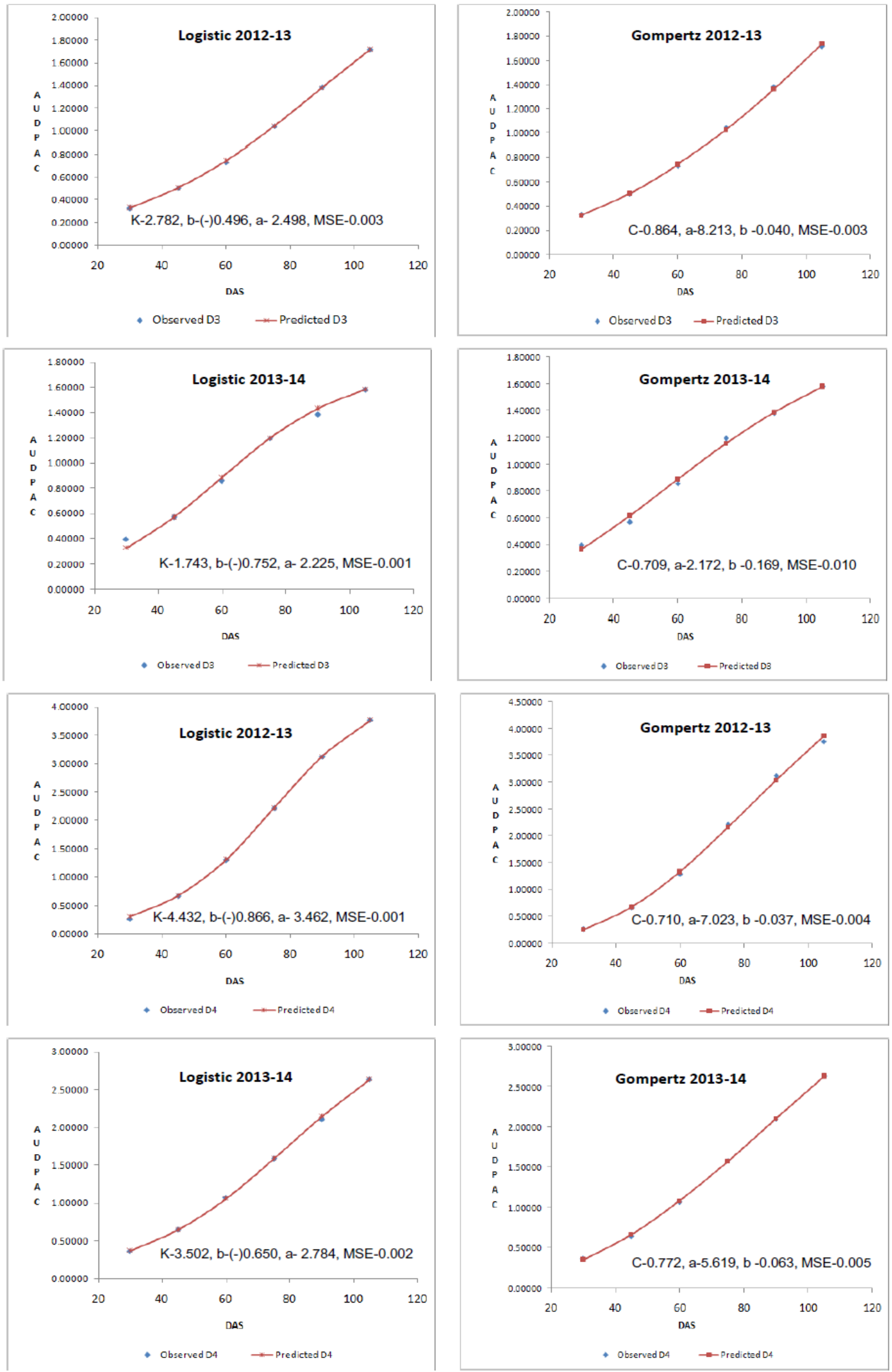

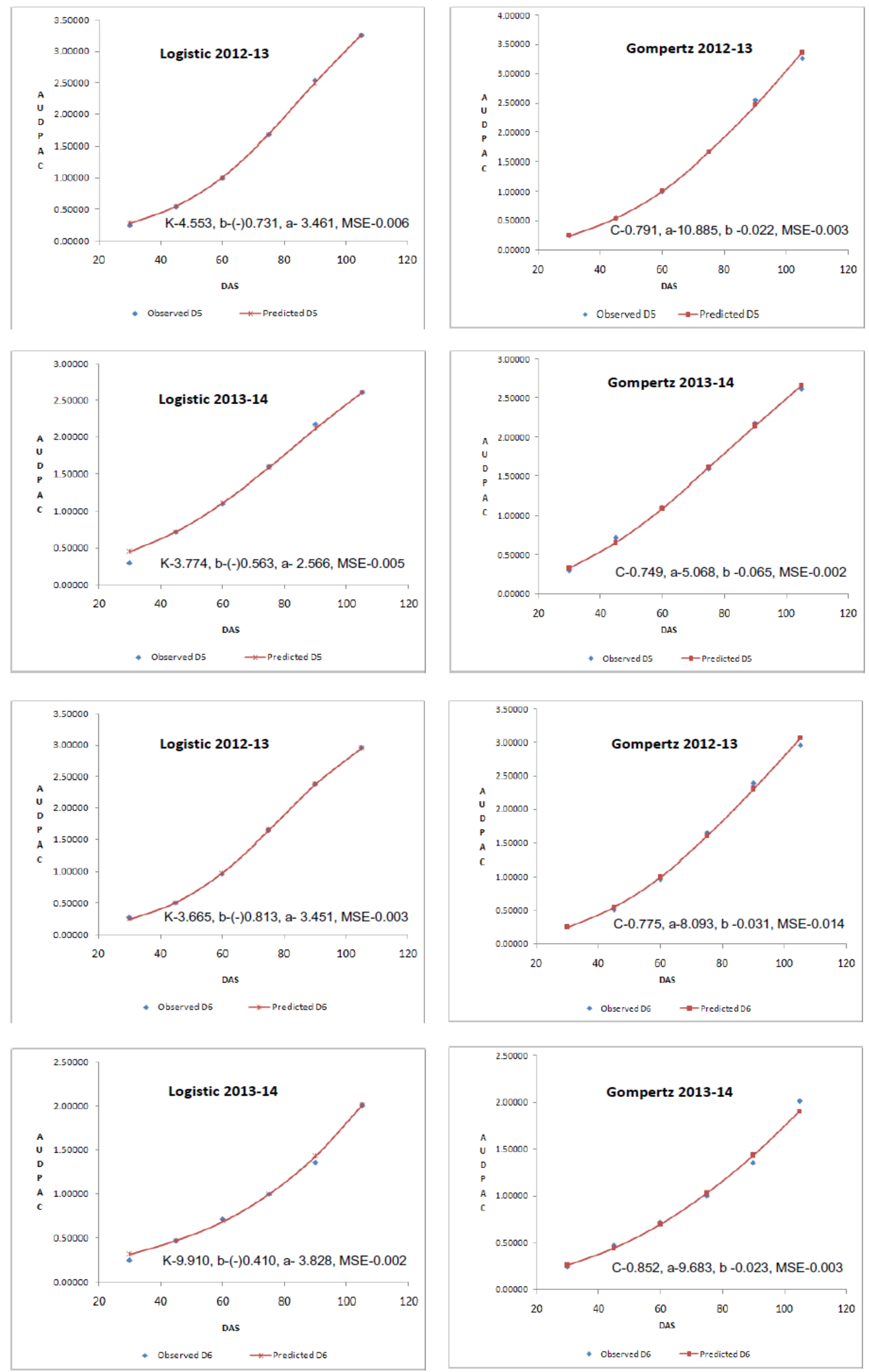

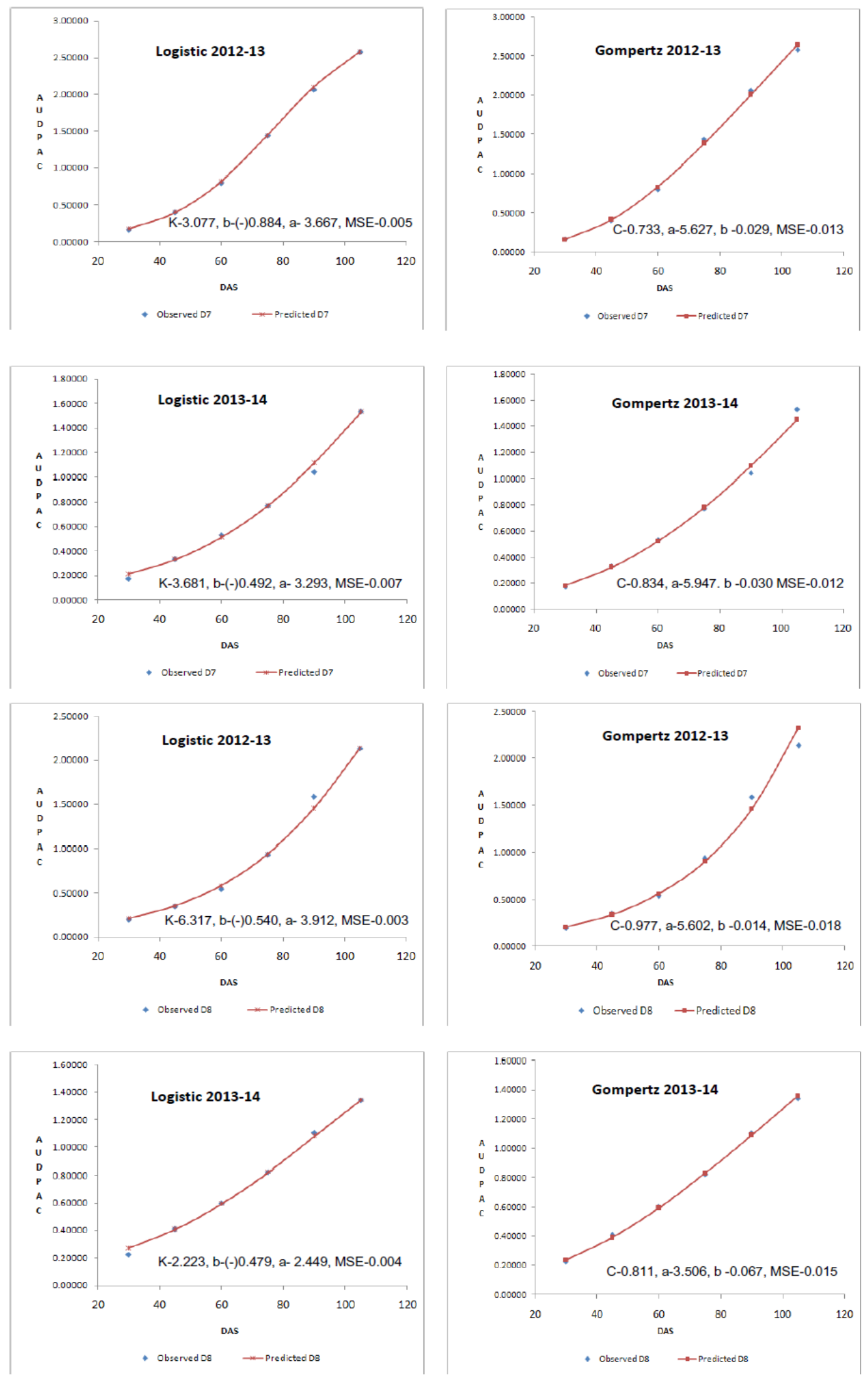

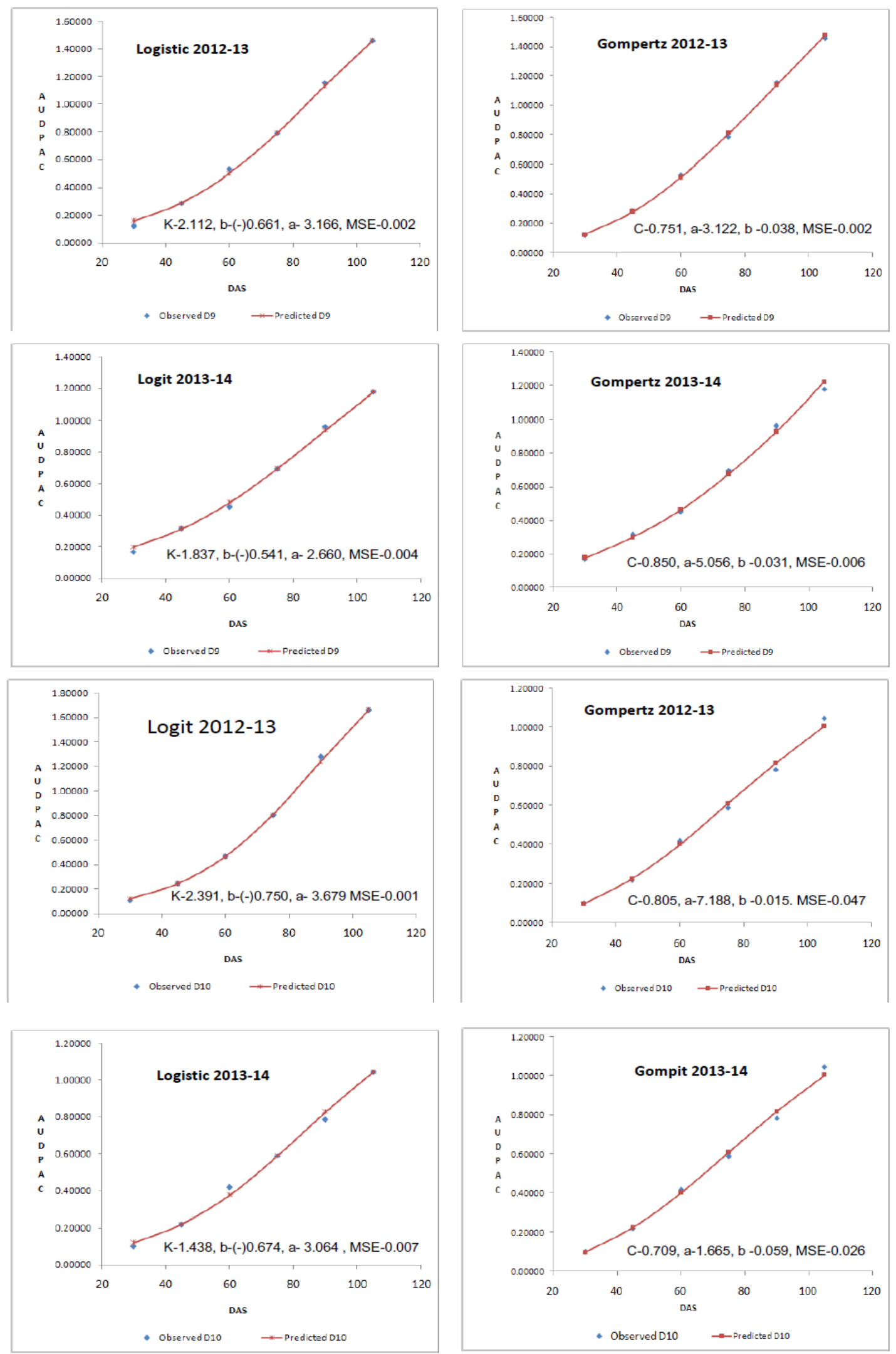
The best fit of one model over the other has been attained by comparison of the regression parameter $Y$ intercept (Fried et al., 1979); $R^{2}$ (Berger, 1981 and Waggoner, 1986) Among the two transformation model, high co-efficient of determination value (R2) of logit and low standard error estimate of logit in both the year prove that logit fit better than gompit in case of tomato leaf curl virua when planted in different dates of planting. In both the year, 2012-13, high co-efficient of determination value $\left(\mathrm{R}^{2}\right)$ of gompit in case of D1, D2 and D5 plot may fit better than logit and low standard error estimate of gompit prove that gompit fit better in this situation (Table 3 and 4). The estimation and comparison of all the parameters in the present investigation resulted in fitting of 88.5 percent and 98.7 percent of the disease progress curves into the logistic and gompertz models, respectively.

From the findings, it can be concluded that in early planting the disease severity is less that the late planting. Planting between $16^{\text {th }}$ August and $31^{\text {st }}$ August found to be best time for planting of tomato under indo-gangetic plains of West Bengal. This finding was also strongly supported by Mohanty and Basu, 1987. Within these planting dates and in $15^{\text {th }}$ october planting disease progression was best defined through gompit model. For the rest of the planting dates logit model was found to fit better. Our experiments had shown good correlation between the two models (coefficient of determination value 0.88 and 0.87 in logistic as well as 0.98 in Gompertz model). Where gompertz value showed 0.98 , it means in case of D6 $\left(30^{\text {th }}\right.$ October planting) there is a change of 98 percent disease severity with the positive significant effect of $\mathrm{T}$ mean, $\mathrm{RH}$ mean and rainfall in combination. It is also applicable under different situations, since the present disease progress curves encompass a wide spectrum of disease severities ranging from
1.43 to 9.9 logistic and 1.66 to 14.29 gompertz apparent infection rates, which are generally encountered under different environmental conditions. These curves will have wider practical applicability in an integrated disease management program, while taking a decision as to whether to take prophylactic measures or not.

\section{References}

Berenson, M., Sevine, D. and Goldstein, M. 1983. Intermediate Statistical Methods and application. Prentice Hall. XVII pp. 579.

Berger, R.D., 1981. Comparison of Gompertz and Logistic equations to describe disease progress. Phytopathology.71: 716-719.

Borah, R.K., and Bordoloi, D.K. 1998. Influence of planting time on the incidence of leaf curl virus disease and whitefly population on tomato. Indian Journal of Virology. 14 (1):71-73.

Butter, N.S., and Rataul, H.S.1973. Control of tomato leaf curl virus (ToLCV) in tomatoes by controlling whitefly, Bemisia tabaci, Genn. by mineral oil sprays. Current Science. 42: 846-865.

Coakley, S.M., Mc. Daniel, L.R. and Shaner, G. 1988. Predicting stripe rust severity on winter wheat using an improved method for analysing meteorological and rust data. Phytopathology.78: 543550.

Fried, P.M., Mackenzie, D.R. and Nelson, R.R. 1979. Disease progress curves of Erysiphe graminis f.sp.triticion chancellor wheat and four multilines. Phytopathology. 95: 151-166.

Friedmann, M., Lapidot, M., Cohen, S. and Pilowsky, M. 1998. A novel source of resistance to tomato yellow leaf curl virus exhibiting a symptomless reaction to viral infection. Journal of American Society of Horticultural 
Science. 123: 1004-1007.

Harrison, B.D., Muniyappa, V., Swanson, M.M., Roberts, I.M. and Robinson, D.J. 1991. Recognition and differentiation of seven whitefly transmitted gemini viruses from India and their relationships to African cassava mosaic and Thailand mungbean yellow mosaic viruses. Annals of Applied Biology.118:299308.

Kranz, J., 1974. The role and scope of mathematical analyse and modeling in epidemiology. In Epidemics and Plant Diseases, Mathematical Analysis and Modeling (Ed. J. Kranz), pp. 7-54 Sringer, New York.

Mahajan, Rajeev. 2001. Investigation on leaf curl virus of tomato (Lycopersicon esculentum). Thesis for M.Sc (Ag) Plant Pathology. Sher-E-Kashmer university of agricultural sciences and technology Jammu. Faculty of Agriculture. R.S. Pura.

Makkouk, K.M., Shehab, S. and Majdalani, S.E.1979. Tomato yellow leaf curl incidence, yield losses and transmission in Lebanon. PhytopathologischeZeitschrift.96:263267.

Mayee, C.D., and Datar, V.V. 1986. Phytopathometry. Technical Buletien1 (Special Bulletin -3), Marathwada Agricultural University Parbhani, India. 218pp.

Mohanty, A.K. and Basu, A.N. 1987. Biology of whitefly vector, Bemisia tabaci Genn. On four host plants throughout the year. Journal of Entomological Research.11: 15-18

Muniyappa, V. and Veeresh, G.K. 1984. Plant virus diseases transmitted by whiteflies in Karnataka. Proceedings of Indian Academy of Sciences.93: 397-406.

Nitzany, F.E. 1975. Tomato yellow leaf curl virus. Phytopathologia Mediterrania. 14: 127- 129.

Pico, B., Diez, M.J. and Nez, F. 1996. Viral diseases causing the greatest economic losses to the tomato crop. II. The tomato yellow leaf curl virus-a review. Science Horticulture. 67: 151196.

Polizzi, G. and Asero, C. 1994. Epidemiology and incidence of tomato yellow leaf curl virus (TYLCV) in greenhouse protected by screens in Italy. Second symposium on protected cultivation of Solanacea in mild winter climates, Adana, Turkey, 13-16 April 1993 [edited by Cockshull, K. E., Tuzel, Y., Gul, A.]. Acta Horticulture. 366: 345352.

Pruthi, H.S. and Samuel, C.K. 1942. Entomological investigation on the leaf curl disease of tobacco in Northern India- V. Biology and population of the whitefly vector (Bemisia tabaci, Genn.) in relation to the incidence of the disease. Indian Journal of Agricultural Sciences.12: 35-37.

Ramos,N., Fernandes, J.E., Arsenio, A.F., Mangerico, S. and Neto,E. 2002. Control of Bemisia tabaci/tomato yellow leaf curl virus complex in tomato nurseries in Portual. EEPO workshop on tomato leaf curl begomo viruses (TYLCV) Faro (PT).

Saha, P. and Das, S. 2014. Development of prediction equations for early blight leaf spot on tomato under different fungicides treatments. Journal of Agrometeorology. 16 (1): 130-136.

Saikia, A.K. and Muniyappa, V. 1989. Epidemiology and control of tomato leaf curl virus in Southern India. Tropical Agriculture. 66:350-354.

Saklani, A.U.D. and Mathai, P.J. 1977. Effect of date of planting on leaf curl disease of tomato. Indian Journal of 
Horticulture. 34: 64-68.

Sastry, K.S.M. and Singh, S.J. 1973. Assessment of loss in tomato by tomato leaf curl virus. Indian Journal of Mycology and Plant Pathology. 27: 274-297.

Shaheen, A.H. 1983. Some ecological studies on whitefly (Bemisia tabaci Genn.) infesting tomato at Mansoura district. Egypt Acta Phytopathologica Academiae Scientiarum Hungaricae. 17: 145-155.

Shanab, L.M. and Awad-Allah, S.S. 1982. Studies on whitefly (Bemisia tabaci Genn.) infesting tomato at Mansoura district. Egypt Acta Phytopathologica Academia Scientiarumhungricae.17: 145-155.

Singh, U.C., Singh, R. and Nagaich, K.N. 1999. Evaluation of tomato varieties against jassid (Empoascadevastans), whitefly (Bemisia tabaci) and leaf curl. Indian Journal of Entomology. 61(2): 173-176.

Vander Plank, J.E.1963. Plant Disease
Epidemics and control. Academic Press. New York. 349 pp.

Varma, J.P. 1959. Tomato leaf curl: ICAR Proceedings, Seminar on diseases of horticultural plants (Simla) pp 182200.

Vasudeva, R.S. and Sam, Raj. 1948. Leaf curl disease of tomato. Phytopathology 18:364-369.

Waggoner, P.E. 1986. Progress curves of foliar diseases: Their interpretation and use. Pages 3-37, In: Plant Disease Epidemiology: Population Dynamics and Management Vol. I. Leonard, K.J. and Fry, E.W. ed., MacMillan publishing Co., New York.372pp.

Wilcoxcon, R.D., Shovm, B. and Asit, A.A.1975. Evaluation of wheat cultivar for the ability to retard development of stem rust. Annals of Applied Biology. 86(2): 275-287.

Yassin, A.M., 1975. Epidemics and chemical control of leaf curl disease of tomato in Sudan. Experimental Agriculture. 11: 161-165.

\section{How to cite this article:}

Madhumita Maity, PolySaha and Partha Sarathi Nath. 2019. Development of Prediction Equations for Tomato Leaf Curl Virus on Tomato at Different Dates of Planting using Logistic and Gompertz Model. Int.J.Curr.Microbiol.App.Sci. 8(05): 910-926.

doi: https://doi.org/10.20546/ijcmas.2019.805.106 